\title{
ANDRZeJ WitKo
}

\section{THE BEGINNINGS OF THE ORDER OF THE MOST HOLY TRINITY AND ITS RULE*}

The Order of the Most Holy Trinity ${ }^{1}$, also known as the Trinitarians, was founded eight hundred years ago by St. John de Matha (d. 1213) ${ }^{2}$. This Saint was born around 1154 in the little Alpine village of Faucon in Provence near today's Barcellonette. His parents were Eufeme, who was from a noble family with

\footnotetext{
- This article constitutes a foretaste of my new book titled Trinitarians, prepared in translation by Ewa Swidzińska Lay, O.SS.T.,Ter. and Kevin R. Lay, O.SS.T.,Ter.

' See C. Mazzarisi di Gesù, LOrdine Trinitario nella chiesa e nella storia, Torino 1964; F. Stro obants, Les ministres généraux de l'Ordre Trinitaire, Marseille 1966; V. Ginarte González, La Orden Trinitaria, Córdoba-Salamanca 1979; T. K n e cht, Histoire de l'Ordre de la Sainte Trinité et de la Redemption des Captifs, [Paris] 1993; J. Puja na, La Orden de la Santísima Trinidad, Salamanca 1993; R. Grimald i-Hierholtz, L'Ordre des Trinitaires, Paris 1994; L. Huy ghues-Despointes, Je briserai vos chaînes. Avec les captifs, Jean de Matha et ses disciples, Montrouge 1995; A.O. D'Errico, The Trinitarians. An Overview of Their Eight Hundred Year Service to God and Humanity [Roma s.a.].

${ }^{2}$ The best monograph on St. John de Matha is the work: G. Llona Rementeria, Fundador y redentor Juan de Mata, Salamanca 1994. To the most important biographies of the Saint belong, from older studies: G. González Davila, Compendio historico de las vidas de los gloriosos san Juan de Mata y s. Felix de Valois..., Madrid 1630; Fran ço is de s. Lau ren S, Abrege de la vie des saincts Jean de la Matte et Felix de Valois..., Aix 1646, p. 3-50; F. Maced o, Vitae SS. Joannis de Matha et Felicis de Valois..., Romae 1660; S. De Malle a, Epitome de las vidas de los gloriosos patriarcas s. Juan de Mata y s. Félix de Valois..., Roma 1665; A. De Andrade, Vidas de los gloriosissimos patriarcas san Juan de Mata y s. Félix de Valois..., Madrid 1668; A. F. Tarizzo, Vita del gloriosissimo patriarca Giovanni di Matha, fondatore dell'inclita Religione della Santissima Trinità, Redenzione de Schiavi, Torino 1698; Mel chor del Es piritu S anto, El patriarca san Juan de Mata, Madrid 1707; F. Garzia, Compendio delle vite delli due Patriarchi s. Giovanni di Matha e san Felice Valesio..., Venezia 1727; Callisto della Providenza, Vita di san Giovanni di Matha, Roma 1894; N. S chu h mach er, Der heilige Johannes von Matha Stifter des Ordens der Heiligsten Dreifaltigkeit, Klosterneuburg 1935. From the newer ones which deserve special attention: E. Es calli r, Le liberateur des esclaves ou le redempteur des captifs saint Jean de Matha, Avignon 1960; A. Romano di s. Teresa, S. Giovanni di Matha fondatore dell'Ordine della SS. Trinità, Vicenza 1961; P. Zabaleta, San Juan de Mata fundador de la Orden de la Santa Trinidad y de los cautivos, Salamanca 1978; G. Antignani, Vita di Giovanni de Matha e ripercussioni della sua opera nei tempi, Siena 1982; R. Cas taño, Nacido para la liberación. San Juan de Mata, Córdoba 1985.
} 
Catalan roots by the name of de Matha ${ }^{3}$, and Martha de Visconti Fenouillet, who came from one of the most important Languedoc families. His first studies were in Faucon, Aix-en-Provence, and probably in Marseille. It was there that he first encountered the social problems of piracy and the captivity of Christians by Muslims. His theological studies were under Guillermo Prevostino of Cremona in the Parisian Studium, soon to become the University of the Sorbonne. After attaining his doctorate, which we know happened between 1190-1192, he began to teach theology, lecturing on the Sentences of Peter Lombard. It is also certain that it was in Paris that he met Lotario Segni, soon to become Pope Innocent III'.

The fall of Jerusalem and its consequence, the undertaking of the Third Crusade, with the participation of the most important monarchs of the Christian world - among them Philip Augustus, Richard the Lion-Hearted and Frederick Barbarossa - resulted in many Christians being taken into captivity ${ }^{5}$.

The fundamental event that had a momentous role in the foundation of the Trinitarian Order was the first Holy Mass of St. John de Matha, said in Paris on the feast of St. Agnes secundo - 28 January 1193 - in the presence of Bishop Maurice de Sully and Fr. Robert, Abbot of St. Victor. According to hagiographical tradition the new priest is said to have asked God for a sign from heaven as to which Order he was to enter. During the consecration, when he elevated the Host, he saw Christ in majesty together with two chained captives - one of white and the other of black race, as well as a blue and red cross. A number of invited guests were also witnesses of this extraordinary vision ${ }^{6}$.

It was precisely this vision that St. John de Matha, founder and first general of the Trinitarians, ordered to be placed on the seal of the Order as its emblem, and around 1210 he had it fixed above the entrance to the Roman hospital San Tommaso in Formis. This Cosmatesque mosaic, which has survived to this day, depicts Christ - Pantocrator holding the hands of two captives: one white, holding in his hand a blue and red cross, and the other black. This mosaic is encircled by the inscription: Signum Ordinis Sanctae Trinitatis et Captivorum .

In order to deliberate on the vision, John went to a solitary place situated in the forest about $80 \mathrm{~km}$ from Paris, named Cerfroid. There he met four hermits spending their time in prayer and fasting. They welcomed him with extreme joy. According to tradition the spiritual master of the hermits was Felix, who came from the royal family of Henri I, and by his mother's family from the princes de

\footnotetext{
${ }^{3}$ On the name de Matha see G. C ipollon e, La casa della Santa Trinità di Marsiglia (1202-15+7), Città del Vaticano 1981 , p. 50-51.

${ }^{4}$ G. Llona Rementería, op. cit., p. 59-75.

${ }^{5}$ G. Cipollo ne, Cristianità - Islam. Cattività e liberiazione in nome di Dio, Roma 1992, p. 393-447

${ }^{6}$ Anton in de L'Assomption, Les origines de l'Ordre de la Très Sainte Trinité d'après les documents, Rome 1925, p. 19ff.; I. Marchionni, Note sulla storia delle origini dell'Ordine della SS. Trinità, Roma 1973, p. 321-323.

${ }^{7}$ See G. Cipollone, Il mosaico di S. Tommaso in Formis a Roma (ca. 1210) contributo di iconografia e iconologia, Roma 1984.
} 
Valois $^{8}$. Felix was born somewhere around 1150 and is said to have received the name Hugo at his baptism. Some say he participated in the Third Crusade under the command of Philip Augustus, and there came to know the suffering of Christians fallen into captivity. Rejecting the vanities of the world, he left the royal court, received Holy Orders, and settled at the hermitage in Cerfroid. Soon a few disciples had joined him, desiring to lead a holy life under his direction. In 1193 John de Matha arrived. Felix not only accepted him but readily offered his cooperation in the work of ransoming Christian captives from pagan hands. The Crusades had resulted in many knights and penitents falling into captivity, hence hospital and redemptive activity had become so important ${ }^{9}$. This activity captured the vivid interest of Parisians, and this made possible the rapid erection of the first houses for the increasing group of co-workers of John de Matha, who was well known in the academic milieu of Paris. At this time he was in the course of writing his own Rule, rather than deriving it from the legislation of other Orders, and was coming to Paris for consultation with the local Bishop and the Abbot of St. Victor. During this period he was also attracting candidates who wanted to follow the pathway he was setting down. After he had been three and a half years at the hermitage, according to Trinitarian tradition, St. John and St. Felix, while sitting by the well in Cerfroid thinking over how to bring their idea of a new Order into effect, saw a stag with a blue and red cross between its antlers and this was for them a sign confirming their aspirations ${ }^{10}$.

As early as 1194, as a result of the gift of Marguerite de Bourgogne, there arose in Cerfroid the first house of the Trinitarian community ${ }^{11}$, followed by foundations in De Planels and Bourg-la-Reine. These places are mentioned in the bull Cum a nobis petitur, dated 16 May 1198, in which Pope Innocent III took under the protection of the Holy See three Trinitarian foundations which were working for the ransom of captives from pagan hands ${ }^{12}$. At this point John de Matha was already in Rome with the Religious Rule he had written. However, the Pope sent him back to France, wanting consultation in this matter with the Bishop of Paris, Odon de Sully, and with Absalom, Abbot of St. Victor. According to tradition, on the feast of St. Catherine of Alexandria, 25 November 1198, Innocent III, while

\footnotetext{
${ }^{8}$ Besides the above given biographies dealing with both patriarchs of the Order see: Calixte de la Providence, Vie de saint Félix de Valois, Paris 1868. The fundamental work on St. Felix is the first monograph in over one hundred thirty years: B. Frat in i, S. Felice de Valois nella tradizione dell Ordine Trinitario, Roma 1998.

${ }^{9}$ Latin word redemptio means ransom, liberation, saving.

${ }^{10}$ F. De Vega y Toraya, Crónica de la Provincia de Castilla, León y Navarra del Orden de la Santissima Trinitad Redención de Cautivos. Primera parte, Madrid 1720, p. 49-52; Anton ino de la As unción, Historia del origen de la Orden de la Santísima Trinitad, Bilbao 1925, p. 40-44. 1978.

"G. Cipollone, Studi intorno a Cerfroid prima casa dell'Ordine Trinitario (1198-1429), Roma

${ }^{12}$ Antonino ab Assumptione, Synopsis bullarii Ordinis Sanctissimae Trinitatis, Romae 1921, p. 5 .
} 
celebrating the Eucharist in the basilica of St. John on the Lateran, had a vision identical in content with that of St. John de Matha during his first Mass. It was this which assured the Vicar of Christ of the rightness of establishing the new Order. This followed officially on 17 December 1198, when Pope Innocent III signed the bull Operante divine dispositionis, approving the Order of Trinitarians and its Rule $^{13}$.

It is important to highlight John de Matha's obtaining of papal approval for the work he had begun. He was not content with the approval of the local Bishop, even though at this time papal approbation was not necessary for the growing Order. Undoubtedly there were a number of reasons for this. First of all the charism of the Trinitarians, involving the ransom of captives, went beyond the borders of one diocese and even of a single country, since its nature was more than national. Secondly the character of the Order and its purpose demanded independence from the territorial authorities. Certainly, too, one cannot overestimate the fact of the personal acquaintance, from their Parisian days, of John and Innocent III. This action of John de Matha was extremely innovative. St. Francis of Assisi followed his example when founding the Order of Franciscans. We see its influence reflected also in the Fourth Lateran Council of 1215, which made the foundation of new Orders dependent on papal approbation ${ }^{14}$.

Before John de Matha left the Eternal City he had received three additional documents from the Apostolic See. In the letter Sacrosancta Romana Ecclesia of 4 January 1199 the Vicar of Christ again took the three existing houses under his protection. One month later the Pope and sixteen Cardinals signed the bull Operante Patre luminum, once again approving the Order of Trinitarians and its Rule, as well as granting to the three existing houses privileges which were usually were given to monasteries. On 8 March the Pope directed the document Inter opera misericordiae to the king of Morocco - Muhammad al-Nâsir residing in Marrakesh. In this letter he presented the Order of Trinitarians as being called to ransom Christian captives by the use of money or the exchange of Muslims ${ }^{15}$.

As Trinitarian tradition has handed it on, it was St. John de Matha himself who set out with the papal letter to Morocco, where he successfully achieved the first ransom of Christians held in captivity. Thereby he began the great redemptive mission of the Order, finding its field of action in Palestine, North Africa and Spain (at this time occupied by the Moors). The activity of the Trinitarians, namely the ransom of Christians from captivity, met with enthusiastic acceptance, and already in the second half of 1199 John de Matha was able to begin the foundation of

\footnotetext{
${ }^{13}$ The text of the original Rule and the most important of its editions, are published by: J. J. G ross, The trinitarians 'rule of life: texts of the six principal editions, Rome 1983.

${ }^{14}$ See J. de Figueras Capri, Chronicum Ordinis Sanctissimae Trinitatis de Redemptione Captivorum, Veronae 1645, esp. p. 1-14; Di eg o de Jes ú s, Anales de la Religión de la Santissima Trinitad Redención de Cautivos Cristianos, vol. I, Madrid 1687, p. 60-64.

${ }^{15}$ I. Marchionn i, op. cit., p. 253; G. Cipoll on e, Cristianità-Islam, op. cit., p. 426-429.
} 
a number of new houses in the South of France, among which that at the port of Marseille was of particular importance ${ }^{16}$. Two years later, thanks to a donation of Pedro de Belvis, he brought about the first Spanish foundation in the village of Avingana, in the diocese of Lérida ${ }^{17}$. In the next few years others appeared, among which those in Toledo (1206), Segovia (1207) and Burgos (1207) were specially significant. In the meantime he carried out a number of redemptions: in 1204 in Tunis, in the years 1207-1208 in Córdoba and Valencia, and in 1209 in Tunis again. ${ }^{18}$

From Viterbo Pope Innocent III issued the bull Operante Patre luminum, dated 21 June 1209, in which he took all existing Trinitarian houses under his apostolic protection. The foundations then comprised: Cerfroid, De Planels, Bourgla-Reine, Marseille, Arles, Saint Gilles, Lérida, Avingaña, Toledo, Segovia, Burgos, Quintana del Rio, Rubios de Broa, San Vicente de Buezo, Tunilla, Barcena, Puente-la-Reina, Châteauneuf près Martigues, Étampes, Gosmedos, Entreiglesias, Rome (San Tommaso in Formis), Daroca and Paris. In the same document are also mentioned the Confraternities of laity in the Kingdom of Aragon, which points to the important dimension of the cooperation between Trinitarian religious and Trinitarian lay persons in the Order's redemptive-hospital work ${ }^{19}$.

In the same year (1209) John de Matha received into his possession the former Cistercian Abbey in Rome near the Colosseum - San Tommaso in Formis which became his residence. There he founded a hospice for the sick, the poor and pilgrims $^{20}$. Soon after its acquisition, he ordered the above - mentioned mosaic, with its image of Christ holding the hands of two captives of white and black race, to be set above the entrance to his new quarters.

There is a lack of unambiguous sources regarding his next foundation or redemptive journeys. It is commonly accepted that he sent religious to accompany the crusaders ${ }^{21}$. John himself, however, led a penitential life, though, as a minister-general and in accordance with the Rule, he was obliged to summon and preside over annual chapters. According to uninterrupted religious tradition, John de Matha died in the house of San Tommaso in Formis in Rome on the 17 December 1213. It was thus exactly fifteen years since the approval of the Order and the Trinitarian Rule. Four days later he was buried in the local church, his earthly remains being laid in a sarcophagus. At his death he left more than thirty religious houses gathered in three areas: in the North of France, in Provence and on the terrain of

${ }^{16}$ G. C ipoll one, La casa della Santa, op. cit.

${ }^{17}$ Antonino de la Asunción, Historia documentada del convento de pp. trinitarios de Avingaña, Roma 1915.

${ }^{18}$ A. Romano di s. Teresa, S. Giovanni di Matha, op. cit., p. 248, 269-272.

${ }^{19}$ I. Marchionni, op. cit., p. 256-258.

${ }^{20}$ Antonino dell'Assunta, A. Romano di s. Teresa, S. Tommaso in Formis sul Celio. Notizie e documenti, Isola del Liri 1927.

${ }^{21}$ Cf. A. Romano di s. Teresa, Nel solco. Appunti storici sulle missioni trinitarie, Roma 1930, p. 35-40. 
Aragon and Castile, each putting into action the religious charism of ransoming captives and service to the poor ${ }^{22}$.

St. Felix is the figure around whom there has been a fierce polemic. Tradition says that after the first redemption in Morocco he settled in his homeland to attend to the inner structure of the Order. He often stayed in the South of France, from where maritime expeditions of Trinitarians were setting off. Indeed in the three source documents Brother Felix appears in connection with the house in Marseille - in 1203 as a witness and in 1208 and 1210 as a house superior. Religious tradition always identified this figure with the Patriarch of the Order, St. Felix de Valois, co-founder of the Trinitarians and the closest co-worker of John de Matha. Hagiography passed on a number of interesting details regarding the Saint, emphasizing his royal origin and his passion for the hermitic life to which he returned in the last years of his life in Cerfroid. We also know the exact date of his death, which came to him on 4 November 1212 at the age of 85 in the first Trinitarian house. It was there that he was to be buried. Among the most well-known episodes of his life preserved in the religious tradition, belongs the description of the extraordinary apparition of the Mother of God together with Angels in Cerfroid. On the night of 7-8 September 1212, that is on the feast of the Birthday of the Blessed Virgin Mary, when the friars had fallen asleep and had not yet appeared in choir, the Blessed Mother came with Angels to accompany the Saint in the singing of Matins (Matutinum). Though for the last four centuries St. Felix de Valois was continuously recognized as a co-founder, because of the lack of knowledge of his life and a number of doubts surrounding him, in 1969 the general chapter of the Order decided to grant the title of founder to St. John alone ${ }^{23}$.

Even though, over the centuries, the images of the two holy Patriarchs were honoured in many places, with many Popes describing them as Saints and even granting special indulgences in their honour, for much of this time they were not recognized officially as Saints. After Urban VIII's introduction, on 15 May 1625, of new regulations on elevation to the altar, many Orders campaigned for the canonization of their founders. After the announcement in 1628 of the canonization of Peter Nolasco, founder of the Mercedarian Order which had also occupied itself with the ransom of captives, the Trinitarians started to strive for the elevation of their own Patriarchs to the altar. In the years 1630-1665, on the initiative of the Spanish Discalced Trinitarians, the process de cultu ab immemorabili was carried through, ending favourably with the decree of the Holy Congregation of Rites and the bull of Pope Alexander VII of 21 October 1666 giving official acknowledgement to the cult of St. John de Matha and St. Felix de Valois as immemorial. This, according to the regulations then current, was tantamount to canonization. Three years later Clement IX approved the formula of Holy Mass and Divine Office, and

\footnotetext{
22 J. Pujana, op. cit., s. 32-35.

${ }^{23}$ B. Fratin i, op. cit.; J. Pujana, op. cit., s. 35-38.
} 
the next year Clement $\mathrm{X}$ wrote both Saints into the Roman Martyrology, fixing as their liturgical celebration 17 December for St. John de Matha and 4 November for St. Felix de Valois. In 1679 Innocent XI moved these feasts to the 8 February for St. John and to 20 November for St. Felix. In 1694 Innocent XII ordered the celebration of their feasts throughout the whole Church. With the reform of the liturgical calendars after Vatican II, the feasts were dropped from the universal calendar and returned on the Order's calendar to 17 December and 4 November ${ }^{24}$.

In the year 1389, during the western schism, the Trinitarians lost their quarters in San Tommaso in Formis in Rome, where St. John de Matha was buried. For several generations it was tried ineffectively to recover the house from the hands of its new owner, which was the Vatican Capitula. The canonical process revived in the Trinitarians the fervent desire to possess the relics of the founder, for which purpose there was no hesitation in committing the blessed fault. During the night of 19 March 1655 two Spanish Trinitarians, José Vidal and Gonzalo de Medina, opened the sarcophagus in the Roman church and found in it three bodies: those of John de Matha and of two of his successors - the second and the fifth generals of the Order - John the Englishman and Miguel the Spaniard. The earthly remains of the Patriarch were then taken and moved to the residence of Fr. Pedro Arias Portocarrero, the general procurator of the Order at the Apostolic See. He transported them to Madrid, where on the 24 November 1655 he handed them over to the Apostolic Nuncio, Camilo de Maximis. Still in the same year in Rome the process super subtractione corporis took place, and two years later in Madrid the process super identitate corporis. In the year 1686 the relics were intercepted by the Discalced Trinitarians, who placed them under the altar of their church in Madrid. Five years later, after the first canonical approval, they were exposed for public reverence. In the meantime some started to question the authenticity of the relics. Moreover, the Calced Trinitarians protested against their being handed over to the Discalced. This caused the intervention of the Congregation of Rites, which finally referred the case to the Pope. Innocent XIII ordered the re-examination of the case and, based on the decree of the above- mentioned Congregation, on 16 September 1721 issued the bull announcing that the relics were the bones of St. John de Matha and could receive public veneration. When, in the Madrid Nunciature and in the presence of many church and lay dignitaries, the relics underwent a detailed autopsy it tumed out that the skeleton was intact. It indicated a tall man. The extraordinary whiteness of all the bones made a special impression. Then the relics were divided between the Calced and Discalced Trinitarians and their transfer,

${ }^{24}$ F. de Arcos, Memorial [...] y un devoto de nuestros Santos Patriarcas San Juan y San Félix, Madrid 1661, passim; Alonso de san Antonio, Gloriosos títulos apostólicos y reales, originarios y privativos de la Sagrada Religión Descalza y Calzada de la Santisima Trinidad, de Redención de Cautivos, Madrid 1661, passim; Congregatione Sacronum Rituum, Canonizationis Servorum Dei Ioannis de Matha et Felicis de Valois Fundatorum Ordinis Sanctissimae Trinitatis Redemptionis Captivorum. Positio super dubio, Romae 1666, passim; J. Puj a n a, op. cit., s. 38-39. 
made on 10 May 1722, inaugurated the memorial of the transfer of the relics which is observed to this day on 7 May. ${ }^{25}$.

In 1749 Pope Benedict XIV offered to the general of the Discalced Trinitarians, Miguel de San José, the original marble sarcophagus from San Tommaso in Formis in Rome, in which the holy Patriarch. had been laid . Today it is preserved in the Archeological Museum in Madrid. Because of the religious suppressions of 1835 the relics of the Saint were brought together again and laid in the comvent of the Trinitarian Sisters of Madrid, from where they were taken to the cathedral during the civil war and finally on 9 October 1966 transferred to the Trinitarian college in Salamanca, where they receive lively reverence to this day ${ }^{26}$.

The Trinitarian Rule approved by Innocent III on 17 December 1198 is a distinct rule, different from traditional classifications and applying to monks, canons regular, orders of knights, and mendicants. Though one can certainly grasp the impact of the environment and the influence of other orders of monks and canons regular, especially of the Abbey of St. Victor, the originality and uniqueness of the Rule of John de Matha appears first of all in the redemptive activity and the more evangelical common life ${ }^{27}$.

That which constitutes the most original threads of the Rule can be gathered into three categories. The first concerns reference to the Most Holy Trinity. The Holy Trinity is already mentioned in the first words of the text of the Rule, defining the title of the new Order and its members: Fratres domus Sanctae Trinitatis. Similarly all the churches of the Order are to bear this title: Omnes ecclesiae istius Ordinis intitulentur nomine Sanctae Trinitatis, and the superior of the house is to be called minister domus Sanctae Trinitatis. Although the annual general chapter was not bound up explicitly with the liturgical celebration in honour of the Most Holy Trinity, it was emphasized that this gathering should take place in Octavis Pentecostes. Some symbolic connections also deserve to be emphasized. Thus in this way should be understood the division of goods into three parts, which was to indicate a reference to the Most Holy Trinity, likewise the three colours of the Trinitarian habit - white, blue and red - were so interpreted. It is readily evident, therefore, that the Trinitarian relation to the Most Holy Trinity was very concrete and visible, far removed from theological-philosophical speculations, and far from representing the Triune God as a mystery and subject of contemplation, rather being above all the foundation of activity directed to the ransom of captives and the service of the poor ${ }^{28}$.

${ }^{25}$ G. Llona Rementería, op. cit., s. 449-459.

${ }^{26}$ Ibidem, op. cit., s. 460-461.

${ }^{27}$ German de la Stma. Trinidad, San Juan de Mata escribió para la Orden de la Santísima Trinidad una Regla propia?, Estudios Trinitarios, vol. II, Salamanca-Cordoba 1964, p. 23-55; J. B or re go, La Regla de la Orden de la Santisima Trinidad, Roma-Salamanca 1973.

${ }^{28}$ I. Vizcargũénaga Arriortua, La Santísima Trinidad y la Orden de San Juan de Mata, Estudios Trinitarios, vol. III, Salamanca 1969, s. 155-270, G. Cipollone, Riferimenti alla Trinità nel periodo delle origini dell'Ordine Trinitario, [w:] La Trinita nella legislazione dell'Ordine Trinitario, Roma 1979, s. 20-27. 
Extremely innovative, though evangelical, is the title of the superior of the Order, who is called minister, and his serving actions which the Rule prescribes towards the brothers. Rejecting the title of superior, the distinction of subject was abolished too, since all were to be brothers. The task of the superior was: omnibus fratribus suis, sicut sibimet minister fideliter administret. Fraternity constituted the essence of the communal behaviour; and fraternal charity was expressed in the equality of clerical and lay brothers with regard to dress, meals, dormitory and refectory. It was manifested too in the open dialogue during weekly chapters, when fratres ministro et minister fratribus were to give account, and in the field of fraternal correction, which was consistent with evangelical principles. Fraternity was also expressed in the avoiding of unjust accusation, in the election of the minister per commune fratrum consilium, and in the obligation of work, which excluded no one. Finally the use of such words as domus or cohabitatio were in order to underline more strongly the familial climate and the fraternity of the religious ${ }^{29}$.

The Rule of the Order dedicated particular space - almost three -quarters of the text - to poverty, especially in the context of the redemptive apostolate and service to the poor. To the most important clauses belonged, in addition to the obligation of work: the precept of division of income into three parts; travelling on an ass; and abstaining from meat and fish. Setting aside one third of the income for the ransom of captives, and a second third for the carrying out of works of charity, ensured it would be impossible for the Order to become rich. The Trinitarians could in no way take for themselves more than one third of the income. Even the common property, as the Rule clearly specifies, such as house, church, lands, vineyards, and cattle, had as its function to make it easier for the religious to undertake the service of charity, not in any way violating their poverty ${ }^{30}$.

The Rule stated that a community should consist of seven religious: four clerics and three lay brothers. It permitted the shortening and mitigation of the obligation of prayer in choir, but ordered prayer in the presence of the sick in the hospitals. It also gave the norms regarding redemptive expeditions. In this light the community is revealed as extremely dynamic, open and active in the undertaking and realization of deeds of mercy, both local and international ${ }^{31}$.

For the redemption of captives the Rule prescribed the division of all the income into three parts. It is the tertia pars that constitutes the characteristic feature of the Order of Trinitarians and its particular originality, which has no equivalent in the history of the religious life $\mathrm{e}^{32}$. Thus the third part - entirely without exceptions or mitigation- was to be assigned to the ransom of the captives. If some benefactor did not accept this, the money would not be received. Also from the beginning, the

\footnotetext{
${ }^{29}$ J. Pu ja na, op. cit., s. 43-44.

${ }^{30}$ G. C jpollon e, Riferimenti alla Trinità, op. cit., s. 40-42.

${ }^{31}$ J. Pujan a, op. cit., s. 45.

${ }^{32}$ G. Cipollone, Cristianità-1slam, op. cit., p. 407-412.
} 
division of the remaining two thirds took place for practical and theological reasons, according to the arithmetical formula: one third for acts of charity and one third for the needs of the house. The weekly chapter was to watch over the faithful preservation of the third part. Although it constituted the core of the Trinitarian Rule, its application from the beginning met with many difficulties. Hence the later changes in the text of the Rule did not leave this part unaffected ${ }^{33}$.

To the acts of charity provided by the Rule belonged cura hospitum et pauperum et omnium euntium et redeuntium. That is, care for the sick, the poor and pilgrims was to constitute the second element of the mission of the Trinitarians. It is worth underlining that it was non potentes, that is the poor, who were entrusted to the Trinitarians' care. The religious guaranteed them not only what was necessary to the body but provided care for the spirit, too. For this reason the Rule obliged common evening prayer in the hospitals. Emphatically it was also about readiness for the administration of the Sacraments, since the sick, already on their first day in the hospital, were to be confessed and given Holy Communion ${ }^{34}$.

Although previously there had been no lack of groups of persons, and even Orders of knights, organizing the redemption of captives, the Order of Trinitarians was simply the first created specifically for this end.

${ }^{33} \mathrm{~J}$. Hern a nd o, La ,tertia pars" en la regla de los trinitarios para el rescate de cautivos: una forma de inversión económica, de economía evangélica. [w:] La liberazione dei "captivi" tra cristianità e islam. Oltre la crociata e il Ğihâd: tolleranza e servizio umanitario, Città del Vaticano 2000, s. 263-308.

${ }^{34} \mathrm{~J}$. Pu j a n a, op. cit., s. 46-47. 